\title{
Testing Efficiency, Size, Productivity and Capital Structure of Microfinance Institutions (MFI's) of Pakistan
}

\author{
Mumtaz Ahmad $^{1 *}$, Shoaib Saleem ${ }^{2}$,Mariam Abbas Soharwardi ${ }^{1}$, Syed Zainul Abdin ${ }^{1}$ \\ ${ }^{1}$ The Islamia University of Bahawalpur, Pakistan*mumtaz.ahmad@iub.edu.pk \\ ${ }^{2}$ KUBEAC, University of Management \&Technology - Sialkot, Pakistan
}

\begin{abstract}
The aim of the study is to test the impact of efficiency, productivity, size and profitability of microfinance institutions on capital structure in microfinance sector. For this, micro finance NGO's are selected to infer and specifically seven NGO's (e.g. Kashf, Safco, Damen, CSC, Akhuwat, Opp and Assassah) were selected.The data is obtained from annual financial statements of these organization ranging 2005-2019 $(t=15$ years $)$. For analysis, regression analysis technique is applied and unit root test is applied to check data stationary. We found role of size and efficiency significant in determining capital structure and productivity insignificant. Planning and implementation mechanism on key performance indicators (KPI's) is suggested to maximize productivity of micro finance institutions. Strategic flexibility is another important aspect to reconsider and bring into operations to enhance productivity.

The results of the study will help to know that how such antecedent's affects capital structure in micro finance sector for performance concern. It will also help to understand psyche of poor borrowers in Pakistan in borrowing. This research is original for theorists, scholars and practitioners and this concept is also important for organizations to know the alarming outcomes when capital becomes adequate and entire cycle moves adversely when funding sources are very less.
\end{abstract}

Key words: Capital Structure, Efficiency, Micro finance Institutions.

\section{INTRODUCTION}

The key success factor behind every business is accurate funds estimation to meet stipulations at corporate plethora [1]. It is uneasy to foretell such financing requirements in each corporate sector and MFI's [2]. As compare to pure financial sector micro finance organization has its own vivacity to assemble capital structure -constructed by donor's funding and internal financing [3].

So, it discloses to work on proper funds planning, arranging \& deployment is very important because there are less sources of finance in micro finance business to eradicate their precautionary requirements [4]. And objectively these funds are planned and deployed to change status of poor peoples into social sustainable individuals [5]. So it is another strong reason to arrange manages funds of this sector accurately [6].

There are numerous factors that reduces poverty and many others those causes reason of this social issue as deducted by thousands of prior researchers [7], [8], [9]. Though, [10] proved significantly that poverty can be alleviated by rich funding sources and supportive institutionalworking capital. [11] Also investigated capital structure determinants in MFI's and have tabulated significant association with sustainability.

This sustainability is acquired with lower risk, timely funds availability and regular funds repayment by borrower [12]. And for financial sustainability such institutes have to meet long term obligations with internal financings and to fill funding pool by short term borrowings [13]. So, the funds management and their associated decisions are executed by institutional governance, has significant link with outreach and performance [14], [15].

The outreach and institutional performance is affected with time variations, funding natures \&financing decisions [16]. But financing strategy fluctuates strongly due to business and contextual changes having significant collision on firm's capital [17]. Such change comprises $\mathrm{n}$ efficiency, sustainability of portfolio, productivity, size, growth and profitability. Therefore, corporate capital is affected with in manufacturing sector [18], Joint ventures [19], non-profit hospital [20], 
and agricultural businesses [21] utility sector [22] and in micro finance institutions in presence of various contextual limitations.

Moreover, Firm's capital is also contrived by nature of resource provider. In micro financing funds providers has two categories i-e informed and uninformed [23]. Thus, informed investor has richorientationto support socially and uninformed participates less in poverty reduction having negatively significant cause on poverty reduction and MFI's capital both [24].

So, when less informed lenders limits their participation then funds becomes scares, costly or rate of interest roses up, a shape of poverty penalty also makes capital structure tight and problematic sequentially and is affected by various with in firm's factors [25]. While, [26] also found similar findings in this regard and have ceased capital structure significant affecting MFI's and commercial banks both.

Moreover, [27]described significant association of sustainability of commercial banks with capital. And this sustainability in MFI's is found due to its determinants i-e gross loan, per borrower cost, loan amount and size having significant impact with and sustainability [28] and alleviation of poverty by proper funds management [29].

In last few decades, microfinance organizations have become an active participant of society in developing and improving status of poor individuals [30]. Therefore, it is considered as a valuable act for society, especially, in developing countries by making poor individuals as self-sustainable [31]. This structure of business is working in two streams; First, Serving poor by developing their standard of life, and, Secondly, making these poor as able to be self-sufficient or sustainable [32].

Comparatively, these both points are considered by microfinance organizations according to their organizational vision [33]. First point is keenly composed for extreme needy, destitute or mentally distracted peoples [34]. While the second one is for those who need little effort can make their selves as self-dependent [35].

For these objectives such MFI institutes need excessive financial resources to deploy [36]. But the pinching factor that tweaks is arrangement of funds and/or sources of money [37]. Evidently, most of these organizations are relying on donations, charities and funding provided by wealthy peoples in favor of intellectual trust [38]. These resources are comparatively less in comparison to poverty in any context [39]. Moreover, less developed procedures for internal funds arrangement are available to microfinance institutions (MFI's). Thus, it has become a serious issue that how any of the MFI may be productive, efficient in achieving target, progressive and profitable. However, due to such shortage of funds what would be financing system of MFI's is the motivation of study when an MFI is less productive, small in size and less efficient. To address these inquiries recent study aim to test the role of efficiency, size and productivity in determining finance requirements, such as, capital structure of microfinance institutions.

Microfinance is widely considered as modern, rich and demand field in research side and it has wider room to conduct surveys contextually. Interestingly, this field is that its underlying base is one "reduction in poverty". Thus, it is very rich concept in itself and also demands rich side of society to make balance as it is operated in recent time. But it becomes adversely suspense if an organization becomes poor in reduction of poverty travel due to its funds flow system. Hence, the study is going to fill the gap by addressing this issue that what are the factors that affects internal financial system of them that is less investigated in local context of Pakistan.

Moreover, capital structure is widely investigated by thousands of researchers in conventional finance. However in micro finance it has limited investigation in both local and international context. So a wider room exits to conduct much more investigations on this area of study contextually. As Pakistan is under researched country [40] in this area therefore study aims to interrogate the impact of efficiency, productivity, size and profitability on micro finance institutions capital structure.

The study reveals important implications for theorists, scholars and practitioners. And the study will help to know that how such antecedent's affects capital structure in micro finance sector for performance concern. It will also help to understand psyche of poor borrowers in Pakistan in borrowing. This concept is also important for organizations to know the alarming outcomes when capital becomes adequate and entire cycle moves adversely when funding sources are very less.

To address such issues stated above recent research is categorized into three sections i-e first part divulge literature, theoretical ground \& hypothesis, secondelaborates research design $\&$ analyses and third part comprehensively explains findings and implications of study. 


\section{LITERATURE REVIEW}

The capital structure is pinched by various organizational factors mainly by firm's productivity, growth, risk level, efficiency and size [41]. Efficiency is defined as the efficient mobilization of funds and other resources [42]. Thus, Indian MFI's efficiency is found significant with debt to equity ratio, ROA and capital to assets ratio [43]. It is the efficiency that is uplifted due to donors and other funds providers - generates access to capital [44] and this efficiency is also boosted by commercial institutions [45]. [46]Comprehended in their study that is significant correlation between efficient availability of funds and productivity with capital of MFI's andoutreaches [47].

However, [48], [49] have also found similar findings about efficiency and capital structure. Moreover, productivity is a factor that has rapidly changed structure of micro financing institutions around the globe with changing policies up to context and tastes. So, [50] has concluded in their study that technological and system innovation have changed people's attitude to utilize micro funds as $93 \%$, proving productivity significant association with organizational capital. Moreover, [51] has also contributed by evaluating efficiency, productivity and capital structure and have concluded significant links.

While, [52] argued in his study that such efficient flow of funds, higher productivity leads MFI's size high on operations and financing requirement too [53] narrated capital of micro funding institutes as a modern issue that can optimally support or defuse institutional size significantly. Thus, [54] found that institute size and financing needs has significant association in Tanzanian context. Hence, [55]-[56] also found parallel results. [57]Said that higher size, more productivity and optimal efficiency leads to bigger figures and these all have significant impact on capital structure. So profitability in conventional institutes and in micro finance institutes in both is found significant with capital structure [58],[59] [60]. So we hypothesized that there is significant role of MFI's efficiency, productivity and size in determiningcapital structure.

\section{METHODOLOGY}

This is prior suggested by literature that capital structure is wan by micro funding institute's size, productivity and efficiency. Thus to check it empirically, we tested the impact of these factors on structure of capital in MFI's. Therefore, study is explanatory and has selected MFI's (NGO's) of Pakistan as population of study and has obtained seven Pakistani NGO's MFI as sample from population of local MFI's.
In practice, such NGO's are found depending on external financings more as compare to others. So, this section of population is hot to test the model empirically to obtain value results. For results main source of the data were audited financial statement of these organizations taken from national database for data collection and analysis. And the sample is operationalized through random sampling used for data collection in order to have generalized results. The adopted sampling does not lead to any biasness because these organizations are working with different clients in all over the Pakistan.

Hence, there is less chance of sample or response biasness. The data type is panel consisting of 2005-2019 financial statements and is obtained from database of Pakistan Microfinance Network. However, herein current investigation capital structure is dependent variable and efficiency, productivity, size \& profitability are independent. In equation (1) $\mathrm{Y}$ is dependent variable i-e capital structure, $\beta_{1}$ to $\beta_{3}$ all are independent variables named as efficiency, productivity and size respectively.

$$
\begin{gathered}
Y=\alpha+\beta_{1} \text { Efficiency }+\beta_{2} \text { Productivity }+\beta_{3} \text { Size } \\
+e \text { (1) }
\end{gathered}
$$

Table (1) Measurement of Variables

\begin{tabular}{ccc}
\hline Variable & Measurement Model & Source \\
\hline Capital Structure & Debt to Equity Ratio & Khan et al., \\
& & $(2014)$ \\
Efficiency & (Total operating expense to Gross & Basharat, \\
& Loan Portfolio) & Arshad \& \\
Productivity & Loans per Loan Officer & Khan, (2014) \\
& & Basharat, \\
& & Arshad \& \\
Size & $\operatorname{Ln}($ Financial Revenue) & Khan, (2014) \\
& & Khan et al., \\
& & $(2014)$ \\
\hline
\end{tabular}

\section{RESULTS}

In this section collected data of the sample is tested and reported here, to meet the basic statistical assumptions data reliability and validity tests are prior conducted and resulted significantly. Further, unit root test is applied to check the data stationary. The unit root comprises on two i-e Phillip Peron test and ADF test. For ADF and Phillips Perron (PP), the lag value criterion has been selected using Schwarz criteria. Akaike and Schwartz criteria were used to determine whether or not included intercept in the test Application. The following table reveals the stationary, 


\begin{tabular}{llllll}
\multicolumn{7}{c}{ Table (2) Unit Root Test for Stationary } \\
\hline Variable & Unit & t. stats & Sig & $01 \%$ C.V & $05 \%$ C.V \\
& Root & & & & \\
\hline Efficiency & ADF & 4.286 & 0.011 & 3.54 & 2.91 \\
& PP & 4.323 & 0.001 & 3.54 & 2.91 \\
Productivity & ADF & 5.22 & 0.000 & 3.54 & 2.91 \\
& PP & 5.40 & 0.000 & 3.54 & 2.91 \\
Size & ADF & 5.50 & 0.000 & 3.54 & 2.91 \\
& PP & 5.56 & 0.000 & 3.54 & 2.91 \\
Capital Structure & ADF & 4.09 & 0.003 & 3.54 & 2.91 \\
& PP & 4.975 & 0.002 & 3.54 & 2.91 \\
\hline
\end{tabular}

The above table provides the detail of study variables that either these are stationary or not. Thus, to check the data stationary ADF test is applied and for conformation Phillip Peron test is also executed, results of both are tabulated here and variables have $\mathrm{p}$ value less than 0.05 shall be non-stationary. So ADF value of efficiency tstats is 4.286, Phillip Peron (PP) is 4.323 and both non stationary $(\mathrm{p}<0.05)$. Productivity is also non stationary with ADF t-value as 5.22 and PP as 5.40. Size is also non stationary as 5.50 ADF and PP value of t-stats is 5.56. Meanwhile, capital structure is also found non stationary with ADF ad 4.09 \& PP as 4.975 respectively. Unit root at $01 \%$ is found as 3.54 and at $05 \%$ is as 2.91. Hence, unit root test concludes all construct of study as non-stationary.

\begin{tabular}{ccccc}
\multicolumn{5}{c}{ Table (3) Regression Analysis } \\
\hline Variable & Coefficient & Stand Error & t. stats & Sig \\
\hline Efficiency & 0.016078 & 0.002473 & 6.501543 & 0.0000 \\
Productivity & $4.17 \mathrm{E}-08$ & $8.73 \mathrm{E}-05$ & 0.000478 & 0.0002 \\
& & & & \\
Size & 0.097114 & 0.030290 & 3.206144 & 0.0022 \\
\hline R-squared & 0.653306 & & Mean dep var & 0.676659 \\
Adjusted R- squared & 0.605351 & & S.D. dep var & 0.365597 \\
S.E. of regression & 0.281925 & & Akaike info crit & 0.396040 \\
Log likelihood & -6.475256 & & Hannan-Quinn & crit \\
Durbin-Watson & 1.223550 & & 0.476317 \\
\hline
\end{tabular}

By following the statistical procedure data stationary is evaluated and it concluded as variables are nonstationary. Therefore, to elaborate further results of study and to have findings linear regression as extension to non-stationary is applied showed in above table, where efficiency of NGO's is found positively significant with capital structure as $0.0000(\mathrm{p}<0.05)$ resulting as efficiency pinches as 16 percent significantly on capital of these MFI-NGO's and t-stats is 6.501543 with 0.01608 coefficient.

Productivity is found positively significant that it plays its role as 4.17 in capital building significant as 0.0002 ( $\mathrm{p}<0.05)$. While, size of the MFI' also affects significantly as 9 percent in it. The coefficient of size is 0.097114 and t-stats is 3.21 . Profitability t-value is 4.02 and coefficient is 0.077 . Moreover, the value of $\mathrm{R}$ Square is 0.65 explaining the model as sixty five percent. And adjusted $\mathrm{R}^{2}$ value is sixty percent. After having the lag the value of Schwarz criterion is $60 \%$ and the Durbin-Watson is 1.22 less than 02 as being much satisfactory. Hence, results indicated that positively significant affecting capital structure except profitability.

\section{CONCLUSION AND POLICY IMPLICATIONS}

In current research four hypothesis are tested and out of these one hypothesis of profitability is rejected and other three of size, productivity and efficiency are accepted those impacting significantly capital structure of micro finance institutions. So, results are coherent to basic theoretical frame and rejected but hypothesis is rejected as stated by literature and has supported its generic concept. Thus, results comprehended that as efficiency of a MFI rises the capital structure is positively affected and supports operational \& financing activities of institutions [61], [62].

Moreover, similar findings are about size and profitability that as size of the MFI's rises in shape of financial revenue capital structure is affected because excessive financial revenue supports institutions financings requirements and helps to renegotiate or continue financial policies. Hence, study concluded significantly that capital structure is being affected by these three factors in $\mathrm{m}$ Microfinance sectors of Pakistan.

The stakeholders associated to this study can take advantage from it because capital structure of MFI's is always hot, crucial and integral part in this sector especially and the study has shown the indicators association towards it. So the NGO's of MFI's are required to work on these beyond the limits to be selfrelying in fund matter. Another finding of our research that can help management of this sector is that launching profitable schemes and putting work force in pressure for funds generation by this way is not found favorable in this sector because it is unaurthognal to mission of this sector.

Hence, management should focus other sides for funds generation than to be profit centric. In last, most important implication is that such effects have directed a theoretical/empirical reason but the implications are not considered in policy matters by practitioners that makes weak estimations and shows poor planning. This implies as MFI management should consider findings in practice as a chunk rather to isolate from these. In further investigations, cross country analysis will provide more comprehensive findings. And comparative analysis of MFI's banks and MFI's NGO's can be investigated. 
Funding: This study received no financial support.Competing Interests: The authors declare that theyhave no competing interests.Acknowledgement: All authors contributed equallyto the conception and design of the study.

\section{REFERENCES}

[1] MacMillan, K., Money, K., Downing, S., \& Hillenbrand, C. Giving your organisation SPIRIT: an overview and call to action for directors on issues of corporate governance, corporate reputation and corporate responsibility. Journal of General Management, 30(2): 15-42, 2004.

[2] Prasad, E., Rogoff, K., Wei, S. J., \&Kose, M. A. Effects of financial globalization on developing countries: some empirical evidence. In India's and China's recent experience with reform and growth, 201-228, 2005. Palgrave Macmillan, London.

[3] Rappaport, E. A Thirst for Empire.Princeton University Press, 2019.

[4] Bashaija, W. (2019). Relationship between Quality Compliance and Financial Stability of Micro Finance Institutions in Rwanda (Doctoral dissertation, JKUATCOHRED), 2019.

[5] Cheshmehzangi, A., \&Dawodu, A. The Review of Sustainable Development Goals (SDGs): People, Perspective and Planning. In Sustainable Urban Development in the Age of Climate Change, 133-156, 2019. Palgrave Macmillan, Singapore.

[6] Bolis, I., Morioka, S. N., \&Sznelwar, L. I. Are we making decisions in a sustainable way? A comprehensive literature review about rationalities for sustainable development. Journal of cleaner production, (145): 310-322, 2017.

[7] Jazid, A. I. M., Ibrahim, P., \& Rashid, U. K. Poverty Reduction through Entrepreneurship Programs. International Journal of Psychosocial Rehabilitation, 23(3): 23-35, 2019.

[8] Hansen, J., Hellin, J., Rosenstock, T., Fisher, E., Cairns, J., Stirling, C. \& Campbell, B. Climate risk management and rural poverty reduction. Agricultural Systems, 172(1): 28-46, 2019.
[9] Fosu, A. K. Growth, inequality, and poverty reduction in developing countries: Recent global evidence. Research in Economics, 71(2): 306-336, 2017.

[10] Kabir, S., \&Salim, R. Two-staged Capital Structure: An Operational Guideline for Islamic Microfinance System.Monash Business School, Department of Economics.ISSN 1441-5429, Discussion paper 05/16, 2016.

[11] Mwirazubi et al. Emerging Paradigms of Financing Tanzanian Microfinance Institutions and their Impact on Financial Sustainability. World Journal of Social Sciences, 6(1): 32 - 44, 2016.

[12] Abrar, A, \&Javid, Y, A. The impact of capitalstructure on profitability of micro finance institutions.SouthAsian journal of management sciences, 10(1): 21-37, 2016.

[13] AmjadIqbal, TanveerAhsan, Xianzhi Zhang. Credit supply and corporate capital structure: evidence from Pakistan. South Asian Journal of Global Business Research, 5(2): $250-267,2016$.

[14] SujaniThrikawala, Stuart Locke , Krishna Reddy. Board structure-performance relationship in microfinance institutions (MFIs) in an emerging economy.Corporate Governance. The International Journal of Business in Society, 16(5): 815 - 830, 2016.

[15] Thrikawala, S. S. Corporate Governance and Performance of Microfinance Institutions (MFIs): A Comparative Study in Sri Lanka and India (Thesis, Doctor of Philosophy (PhD)).University of Waikato, Hamilton, New Zealand, 2016.

[16] DarushYazdanfar, Peter Öhman. Capital structure dynamics among SMEs: Swedish empirical evidence. The Journal of Risk Finance, 17(2): 245 - 260, 2016.

[17] ChimwemweChipeta, CheraDeressa. Firm and country specific determinants of capital structure in Sub Saharan Africa.International Journal of Emerging Markets, 11(4): 649 - 673, 2016.

[18] Titman, S. and Wessels, R. The determinants of capital structure choice.The Journal of Economic Theory, 43(1): 1-19, 1988. 
[19] Boateng, A. Determinants of capital structure: evidence from international joint ventures in Ghana. International Journal of Social Economics, 3(1): 56-66, 2004.

[20] Wedig, G., Sloan, F.A., Hassan, M. and Morrisey, M.A. Capital structure, ownership, and capital payment policy: the case of hospitals. Journal of Finance, 43(1): 21-40, 1988.

[21] Jensen, F.E. and Langemeier, N. Optimal leverage with risk aversion: empirical Evidence.Agricultural Finance Review, 56(1): 85-97, 1996.

[22] Miller, M.H. and Modigliani, F. Some estimates of the cost of capital to the electric utility industry. American Economic Review, 56(3): 333-91, 1966.

[23] Banerjee, S. B., \& Jackson, L. (2017). Microfinance and the business of poverty reduction: Critical perspectivesfrom rural Bangladesh. Human relations, 70(1): 63-91, 2017.

[24] Tassel, V, E. Subsidies and capital markets: implications for microfinance loan portfolios. Oxford Economics paper, 68(2): 398-418, 2016.

[25] Gutiérrez-Nieto, B., Serrano-Cinca, C., CuéllarFernández, B., \& Fuertes-Callén, Y. The Poverty Penalty and Microcredit. Social Indicators Research, 133(2): 455-475, 2017.

[26] Bayai, I. \&Ikhide, S. Financing and financial sustainability of micro finance institutions (MFI's): A conceptual View. Banks and Bank Systems, 11(2): 21-32, 2016.

[27] Samuel \&Kanini, D. Effect of capital structure on financial performance of commercial banks in Kenya. South Eastern Kenya University.Digital Repository, 2016.

[28] Mahapatra, S.M., \&Dutta, S. Determinants of sustainability of microfinance sector in India. Journal of Rural Development. 35(3): 110-121, 2016.

[29] Banerjee, B, S. Microfinance and the business of poverty reduction: Critical Perspective from Rural Bangladesh.Human Resource Digest. 70(1): 63-91, 2016.

[30] Chowdhury, R., \&Willmott, H. Microcredit, the corporatization of nongovernmental organizations, and academic activism: The example of Professor Anu Muhammad. Organization, 26(1): 122-140, 2019.

[31] Yang, Y., de Sherbinin, A., \& Liu, Y. China's poverty alleviation resettlement: Progress, problems and solutions. Habitat International, 98: 102135, 2020.

[32] Li, D., Weng, Y., Yang, X., \& Zhao, K. SelfDeprecation or Self-Sufficient? Discrimination and Income Aspirations in Urban LabourMarket Sustainable.Development. Sustainability, 11(22 ): 62-78, 2019.

[33] Khurram, S., Khurram, A., \&Memon, M. A. Stakeholder salience and collaboration decisions in microfinance organizations: Evidence from developing Islamic country's context. Strategic Change, 28(6): 479-497, 2019.

[34] Mersland, R., Nyarko, S. A., \&Szafarz, A. Do social enterprises walk the talk? Assessing microfinance performances with mission statements. Journal of Business Venturing Insights, 11, e00117, 2019.

[35] Alexandrescu, L. Streets of the 'spice zombies': Dependence and poverty stigma in times of austerity. Crime, Media, Culture, $1741659019835274,2019$.

[36] Beisland, L. A., Djan, K. O., Mersland, R., \&Randøy, T. (2020). Measuring Social Performance in Social Enterprises: A Global Study of Microfinance Institutions. Journal of Business Ethics, 1-21.

[37] Gläser, J., \&Velarde, K. S. Changing funding arrangements and the production of scientific knowledge: introduction to the special issue.Minerva, 56(1): 1-10, 2018.

[38] Al-Azzam, M. D. Financing microfinance institutions: subsidies or deposit mobilization.Applied Economics, 51(15): 16211633, 2019.

[39] Liu, J., Xia, M., Chen, R., Zhu, X., Liao, Q., Ye, D., ...\& Yu, Y. A membrane-less visible-light responsive micro photocatalytic fuel cell with the laterally-arranged $\mathrm{CdS} / \mathrm{ZnS}$-TiO2 photoanode and air-breathing $\mathrm{CuO}$ photocathode for simultaneous wastewater 
treatment and electricity generation. Separation and Purification Technology, 229: 115821, 2019.

[40] Aycan, et al. (2000). Impact of Culture on Human Resource Management Practice: A 10-Countries Comparison.Applied Psychology.An International Review, 49(01): 192-221, 2000.

[41] Li, Y., Zhong, Z., Guan, J., Zhou, J., \& Li, J. (2020). Firm size affecting efficiency of production and commercialization of knowledge: embedded in cluster development. Asian Journal of Technology Innovation, 28(1): 94-118, 2020.

[42] Bodas-Freitas, I. M., \& Corrocher, N. The use of external support and the benefits of the adoption of resource efficiency practices: An empirical analysis of european SMEs. Energy Policy, (132:), 75-82, 2019.

[43] Chaudhury, R. B. \& Bhadra, S. Total factor productivity of Indian micro finance institutions. Indian Institute of Foreign Trade.Working Paper, EC-15-27, 2015

[44] Dees, J. G., \& Anderson, B. B. Sector-bending: Blurring the lines between nonprofit and forprofit. In In search of the nonprofit sector, 6586). Routledge, 2017.

[45] Mustafa, F., Khursheed, A., \& Fatima, M. Impact of global financial crunch on financially innovative microfinance institutions in South Asia. Financial Innovation, 13(4): 1-11, 2018.

[46] Cull, R., Kunt, A. D., \&Morduch, J. Financial performance and outreach: A global analysis of lending micro banks. The Economic Journal, 117(1): 107-133, 2007.

[47] Wijesiri, M., Yaron, J., \& Meoli, M. Assessing the financial and outreach efficiency of microfinance institutions: Do age and size matter? Journal of Multinational Financial Management, 40: 63-76, 2017.

[48] Servin, R., Lensink, R., van den Berg, M. Ownership and technical efficiency of microfinance institutions: empirical evidence from Latin America. Journal of Banking and Financ, 36(7): 2136-2144, 2012.

[49] Piot-Lepetit, I., Nzongang, J. Financial sustainability and poverty outreach within a network of village banks in Cameroon: a
multi-DEA approach.European Journal of Operational Research, 234 (1): 319-330, 2014.

[50] Demombynes, G., Thegeya, A. Kenya's Mobile Revolution and the Promise of Mobile Savings. Poverty Reduction and Economic Management Unit,The World Bank, Washington, DC, Policy Research Working Paper no. 5988, 2012.

[51] Cuellar-Fernandez et al. Determinants of margin in micro finance institutions.Journal of Applied Economics, 48(4): 300-311,2015.

[51] Wijesiri, M., Viganò, L., Meoli, M. Efficiency of microfinance institutions in Sri Lanka: a two-stage double bootstrap DEA approach.Economic Model, 47: 74-83, 2015.

[52] Robinson, M. The Microfinance Revolution: Sustainable Finance for the Poor.The World Bank, Washington, USA, 2001.

[53] Ledgerwood, J and White, V. Transforming Microfinance Institutions: Providing Full Financial Services to the Poor.The World Bank, Washington, USA, 2006.

[54] Mwizarubi et al. Emerging Paradigms of Financing Tanzanian Microfinance Institutions and their Impact on Financial Sustainability. World Journal of Social Sciences, 6(1): 32 - 44, 2016.

[55] Kai H. Competition and wide outreach of Microfinance Institutions.Economics Bulletin, 29(4): 2628-2639, 2009.

[56] Kindie B.A. Financial sustainability of microfinance institutions (MFIs) in Ethiopia.European Journal of Business and Management, 4(15): 1-11, 2012.

[57] Mia, M.A., Nasrin, S. \& Cheng, Z. Qual Quant. Quality, quantity and financial sustainability of microfinance: Does resource allocation matter? Quality \& Quantity, 50(3): 1285-1298, 2016.

[58] Kshetri, N. The Indian environment for entrepreneurship and small business development.StudiaNegotia, 56(4): 35-52, 2011.

[59] Kinde, B.A. Financial sustainability of microfinance institutions (MFIs) in 
Ethiopia.European Journal of Business and Management, 4(15): 1-10, 2012.

[60] Diop, N. Gender equality and sustainable development: Achieving the twin development goals for Africa. Brief for the Global Sustainable Development Report, 2015.

[61] Hoque, M., Hoque, M., Chishty, M., \&Halloway, R. Commercialization and changes in capital structure in microfinance institutions. Managerial finance, 37(5): 414425, 2011.

[62] Khachatryan, K., Baghdasaryan, V., \&Hartarska, V. Is the model "loans plus savings" better for microfinance in Eastern Europe and Central Asia? A propensity score matching comparison. Review of Development Economics, 23(3): 1309-1330, 2019. 